Gadjah Mada International Journal of Business

September-December 2008, Vol. 10, No. 3, pp. 375-391

\title{
THE ROLE OF INTENTION TO CONSUME IN CREATING AUTOBIOGRAPHICAL MEMORY
}

\author{
Jony Oktavian Haryanto
}

Children are a unique and also potential market. They are unique because they usually do not spend their own money but they may have high purchasing power back-up. They are potential because from the number of kids and the amount they spend, they are big and promising. Markets for kids consist of three markets: (1) primary market that targets the children itself, (2) influence market that emphasizes the influence that the children exert on family purchases, and (3) future market that considers the future market for the children. Based on the high potential market for the children, the author identifies the impacts of intention to consume for children on influence power (an effort pursued by kids in order to frequently and successfully influence parents or people surrounding them), impulsive buying (kids' tendencies to buy spontaneously, immediately, and without any deep consideration), and autobiographical memory (a memory of previous experience that will be stored as a long-term memory). Furthermore, it is necessary to identify the antecedents of autobiographical memory for children. The results show that the intention to consume positively influences the impulsive buying as well as the autobiographical memory. For managerial implications, marketers need to put an emphasis on stimulating the intention to consume in order to create a positive autobiographical memory.

Keywords: autobiographical memory; marketing to kids; intention to consume 
Children are a unique and also potential market. They are unique because children usually do not spend their own money, but they could have high purchasing power backup. They are potential as in terms of number and spending, they are big and promising (Yusuf 2007). Based on his research in Jakarta in 2007, he finds that kids' spending in Jakarta was more than IDR10 trillion. McNeal (1999) provides data about expenditures for children advertising, showing that the advertising costs more than USD1 million only in the United States; more than USD4.5 million for marketing promotion such as coupons, contests, and for the development of marketing programs and clubs specific for children; more than USD2 million for public relations such as publicity, event marketing, and broadcast; more than USD3 million for designing products for children.

McNeal (1992) states that markets for kids are composed of three markets: (1) primary market which targets kids as end users; (2) influence market that targets parents, people around kids, and kids themselves altogether; and (3) future market which targets kids as a potential market in the future. Kids in this article are defined as children aged between 10 and 12 years old. Erickson (1950) categorizes these kids into school-aged kids. These kids tend to realize their responsibilities, try to behave well, and begin doing appropriate things. In this age, they obtain values from morale development and recognize the differences among people and cultures. They could also differentiate between good and bad things.

Acuff and Reiher (1997) reveal that kids between 10 and 12 years old are on the phase of thinking development. They explain that in this phase, kids start focusing on neurological development of left brain. Furthermore, this phase is crucial due to the development of the way kids view their environments and define themselves to adjust to the world surrounding them. Kids are very impressive. They like to imitate celebrities, sports stars, or other role models like teachers, parents, or spiritual leaders. Kids have been chosen because they are considered sufficiently mature to handle simple questions, meaning that they understand the questions being asked. Furthermore, Acuff and Reiher (1997) state that kids on this stage have been able to memorize many events that happen, and bring these memories to adult life. This behavior is rendered by the shift in dominance from right brain to the left brain. Lindstorm and Seybold (2007) explain that children on this phase have already had reasoning for every action that they make. They have had an explanation for every good or bad thing that they do. These all considerations have led kids aged 10-12 years to be chosen in this research.

Research on the intention to consume for kids and on their influence on parents - that finally brings the longterm memory to the future- - areneeded to understand kids' power in influencing parents on buying decisions as 
well as consistent marketing strategy from service providers and other factors that can disrupt kids as customers. This influence power is increasing due to the decreasing number of children within a family, leading to rising importance of better understanding the children (McNeal and Hwa Yeh 1996).

Object proposed here is McDonald's because kids' familiarity to McDonald's is high compared to other fast food restaurants. McDonald's also pays attention to kids, shown by its provision of playing arenas for kids, familiar character of Ronald McDonald's, special gifts for kids, and special products for kids. In this context, McDonald's is a bundle of products consisting of every facility and variance of the products offered. Based on the FGD, it is found that McDonald's could create memories for children with certain circumstances, i.e., when children are highly involved with McDonald's due to their strong preferences toward products. For children in Jakarta, McDonald's could be classified as a low involvement product. On the other hand, in Semarang (not in the down town but the rural area of Semarang), McDonald's is perceived as a high involvement product.

This paper proposes six hypotheses to see the antecedents of autobiographical memory development for kids. Autobiographical memory per se is defined as a memory from previous experience that will be stored as a long-term memory (Braun et al. 2002). A previous experience is the keyword that differentiates an autobiographical memory from a long-term memory. Furthermore, Rubin (2006) explains that an autobiographical memory happens when a specific event is recalled with a specific image. This recall as well as the previous experience differentiate an autobiographical memory from a long-term memory. If kids have already had an autobiographical memory with certain products, brands, or service providers, their buying decision will be affected in the future. This could be persistent until the kids become adults, and these kids can be consistent and loyal to consuming the products. Based on the explanation above, it is expected that the autobiographical memory will have a significant role that is very important to the marketing to kids. If marketers are able to identify the antecedents of autobiographical memory, they can harness it as sustainable competitive advantages.

\section{Theoretical Background}

\section{Intention to Consume for Kids}

Intention is defined as the subjective possibility of a person to conduct a certain action (Brown 1998). This is developed when a person makes a plan about his or her future behavior. Shoham and Dalakas (2003) suggest that intention is a basic unit in the network plan when a person conducts a cognitive action which is future oriented. Intention is based on the future action. Furthermore, they explain that there are three constructs regarding 
Gadjah Mada International Journal of Business, September - December 2008, Vol. 10, No. 3

the intention: (1) intention as a hope (2) intention as a plan, and (3) intention as a want. In the beginning, the author uses these three constructs to measure the intention for kids. However, based on FGD, it is found that kids could not differentiate between hope and plan. Accordingly, it is difficult for them to understand about planning, and that is why hope and want are utilized to measure the intention to consume for kids.

Construct intention as an expectation is the most commonly used and popular in research (Rook 1987). This refers to the individual assessment regarding the subjective possibility that will determine his or her future behavior. Basically, measurement of the intention to consume involves attitudes and subjective norms based on behavioral intention theory (Dittmar and Drury 1998). Behavioral intention is usually predicted based on the multiattribute model (Dittmar and Drury 1998). Darley and Lim (1986) conduct research using technology acceptance model (TAM) as a multi-attribute model to predict the intention to consume technology based on its utility. Dittmar and Drury (1998) define the attitude to consume as a positive or negative feeling toward the next target behavior. Hence, Dittmar and Drury argue that the intention to consume depends on the strength of conducting a specific action.

For kids, there is no specific definition with respect to the intention to consume. Therefore, the author adapts the definition of intention to consume based on the definition for adults. Intention to consume instead of intention to buy is used because kids are different on account of their purchasing power. For instance, kids may have

\section{Figure 1. Conceptual Framework}

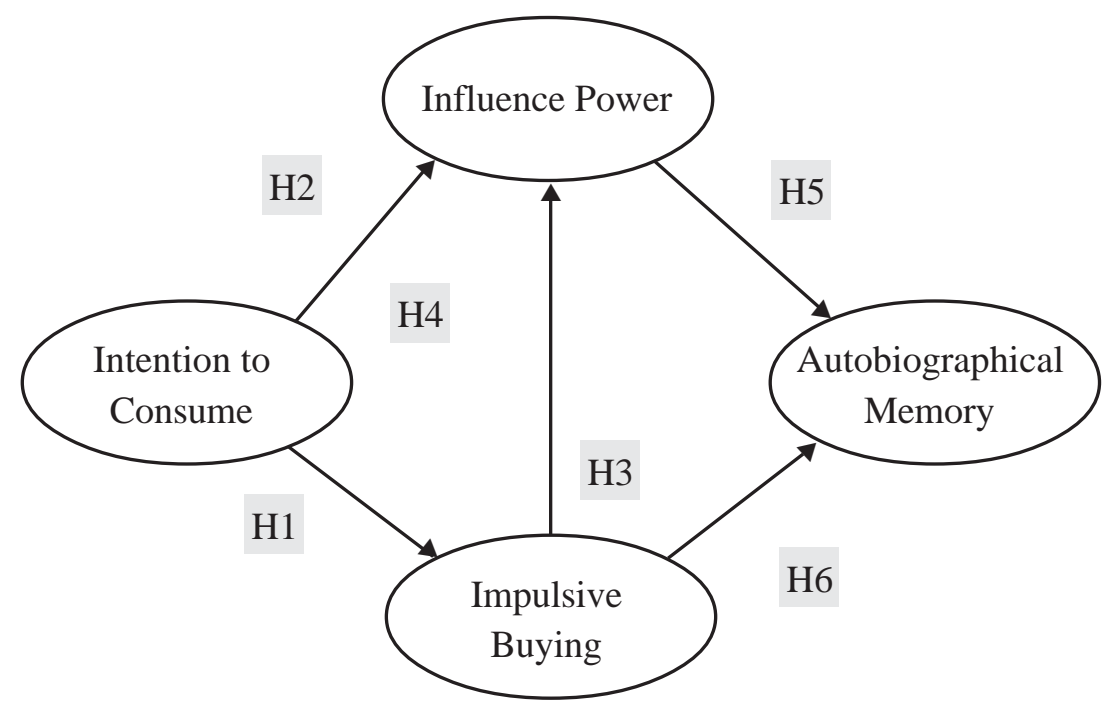


Haryanto-The Role of Intention to Consume in Creating Autobiographical Memory

intention to consume, but it is their parents who conduct the purchases. Hence, intention to consume is preferred to intention to buy.

\section{Impulsive Buying for Kid}

Peck and Childers (2006) define impulsive buying as consumers' tendency to buy spontaneously, immediately, and without any deep considerations. Dittmar and Drury (2000) reveal that the model of impulsive buying has become a trend due to the increasing marketing efforts from marketers. This impulsive buying happens because of the increasing stimulus in the retail environment, e.g., placement of interesting shelving (Abratt and Goodey 1990).

Kids that conduct impulsive buying will feel happy (Cobb and Hoyer 1986; Rook 1987). They also feel that their needs and wants for pleasure are fulfilled (Hausman 2000). Previous research has shown that the intention to consume influences impulsive buying (John 1999; Rook and Fisher 1995; Ramanathan and Menon 2002). On the other hand, this impulsive buyingleads kids to influence parents (Hausman 2000).

When kids have intention to consume, they would prefer to consume right away. This is an active response from 10 -12 year-old kids to their needs that they manifest spontaneously, and it could not be postponed (Peck and Childers 2005). Because of this spontaneous stimulus, kids tend to commit impulsive buying whenever they want certain products. Drittmar and Drury (2000) explain that the tendency of individuals to conduct impulsive buying will be higher if they use that the as a compensation for developing selfimage. In addition, it also happens when there is a high gap between ideal self-concept and perceived self-concept. Kids aged $10-12$ years are in a condition where the development of self-concept is stronger compared to that in other phases (Erickson 1959). In conclusion, kids will conduct stronger impulsive buying than do adults when they have already possessed an intention to consume. More formally, H1: The stronger the intention to consume for children, the higher their possibility to conduct impulsive buying.

\section{Influence Power of Kids}

Scholars have increased their attention regarding purchasing decision on kids due to the enhancement of kids' influence on family, which in turn increases the bargaining power of children. Kids' influence on family purchasing decision is getting stronger nowadays (Shoham and Dalakas 2005; Berkman et al. 2003; Isler et al. 1987).

Influence power of children, often known as pester power, is defined as an effort done by kids in order to influence parents or people surrounding them frequently, sometimes frontally, and successfully (Nicholls and Cullen 2004). The range of this influence depends on the product groups, 
Gadjah Mada International Journal of Business, September - December 2008, Vol. 10, No. 3

the nature of relationship between parents and kids, and also the ages of the kids (Gunter and Furnham 1998).

Previous research has shown that the intention to consume for kids influences kids in persuading parents (Foxman and Tansuhaj 1988; Darley and Lim 1986; Williams and Veeck 1998). This influence power significantly pushes parents to conduct purchases for their kids as they fear or feel uncomfortable to see their kids cry (Ward and Wackman 1972; John 1999). In relation to kids' memory, influence power strongly exerted before getting the result will be memorized firmly in their memories and even until they turn to be adults (Holdert and Antonides 1997).

When kids posses the intention to consume a specific product, they will spontaneously ask their parents and show significant emotional responses in order to get the product (McNeal 1999; Lindstrom 2007). In daily life, it is often observed that kids cry, scream, or get angry when they want a product but being rejected by parents. Kids will employ all techniques they know to influence and force parents to purchase the product. More formally,

H2: The higher the intention to consume, the stronger kids' influence on parents to purchase.

When kids have an intention to conduct impulsive buying, they will influence their parents to purchase the product. This becomes stronger due to the urgency to consume for kids. Techniques and approaches that more em- phasize emotional side make the influence power of kids stronger. Sadock and Sadock (2007) explain that in psychology, this is called "temper tantrum,” i.e., a clinical response like screaming, crying, or getting really angry when their needs or wants are not be accommodated by parents.

Hausman (2000) conducts research that provides evidence that impulsive buying will stimulate kids to influence parents due to the unstable emotion of the kids. This will lead to kids demanding without any consideration, and the kids require that the requests be fulfilled immediately. Kids are basically on a stage in which emotion is more dominant than rationale, thereby making urgency to consume very high. Because kids do not have their own purchasing power, they will influence parents to conduct purchasing for them. In a more formal statement, the author proposes a hypothesis as follows:

H3: The higher the kids' desire to conduct impulsive buying, the stronger their influence on parents.

\section{Autobiographical Memory for Kid}

An autobiographical memory is defined as a memory from previous experience that will be stored as a long-term memory (Braun, etal. 2002). A previous experience is a keyword that differentiates an autobiographical memory from a long-term memory. On the other hand, Solomon (2007) defines a long-term memory as a pro- 
Haryanto-The Role of Intention to Consume in Creating Autobiographical Memory

cess of acquiring information and storing it over time such that it will be available when needed. Rubin (2006) explains that an autobiographical memory occurs when a specific event is recalled with a specific image. For instance, when kids have a specific experience, such as eating at McDonald's, they will make a recall to the experience in association with cheer, cleanliness, etc.

Consumer memory about branding or branding experience in childhood will have significant consequences on the next decisions due to the emotional attachment established beforehand (Lindstrom and Seybold 2007). In this matter, an autobiographical memory is perceived as a trustworthy record with specific visualization that would create an original experience, i.e., an unforgettable experience in life. Sutjan et al. (1993) show that a positive autobiographical memory will lead to a positive attitude toward advertising, and will also enhance brand evaluation. When an autobiographical memory has been developed, it will influence kids' choices or preferences (Bertsen and Rubin 2002).

In relation to product consumption, the positive or negative experience will be memorized strongly in the autobiographical memory. A positive experience of consuming products will stimulate kids to conduct further consumption, and vice versa. Kids with experiences of consuming products and intentions to repeat consumption due to their satisfaction willmemorizethese experiences in their autobiographical memories. In other words, these experiences will be memorized continuously, leading to intentions to repeat consumption.

When kids demand for a specific product continuously, they will memorize it and this becomes an autobiographical memory. This memory turns out to be nostalgia that is continuously prevalent until the kids become adults. In conclusion, the intention to consume is highly connected with the positive experience about the product that they have consumed, and the experience brings a strong autobiographical memory about a specific product or brand. More formally,

H4: The stronger the intention to consume, the stronger the autobiographical memory developed between the kids and the products.

It has been explained that kids have power to influence parents. When kids use their rationality or emotion in influencing their parents, they will strongly memorize this process (Nicholls and Cullen 2003). Kids will use techniques to influence parents, and when they learn that the techniques work well, they will use the techniques continuously until those techniques do not work anymore (Zoll 2000). When kids understand that they have power to influence parents, they will learn that they possess bargaining power to attain what they want, and they will also memorize this continuously (John 1999).

When kids get a particular product with a lot of efforts - such as crying, screaming, or using influence 
Gadjah Mada International Journal of Business, September - December 2008, Vol. 10, No. 3

power - they will not forget these endeavors easily. These moments will be memorized to a stronger extent in their autobiographical memories (Santrock 2001). In conclusion, when kids use their influence power, they will record it in their autobiographical memories and establish emotional attachments with products that they want with the influence power. Based on the explanation above, the author proposes the following hypothesis.

H5: The stronger the influence power, the stronger the autobiographical memory developed between the kids and the products.

Kids conducting impulsive buying will feel happy (Cobb and Hoyer 1986; Rook 1987). They will also feel that their needs and wants for pleasure are fulfilled, thereby creating a strong autobiographical memory to the product (Hausman 2000). Cobb and Hoyer (1986) prove that impulsive buying will push the development of the autobiographical memory of the product even if it is mediated by loyalty to the product. Dittmar and Drury (2000) explain that motivation holds a more dominant role compared to price or utility. Kids often buy or consume products only because they will make them feel better, being themselves, or able to express something about themselves. In other words, impulsive buying is conducted to enhance self-concept and mood. Impulsive buying here is defined as kids' tendencies to buy spontaneously, right away, and without any deep consideration (Peck and Childer 2006).
Kids are on the stage of strong development of self-concept, so impulsive buying that they do in order to develop self-concept will be recorded in their autobiographical memories. This is established due to the habituation process where kids are habituated to consume so as to create lower alternatives to competitors. Impulsive buying by kids will be memorized in autobiographical memories; accordingly, the more often they conduct impulsive buying, the stronger they will memorize it.

H6: The more often the impulsive buying, the stronger the autobiographical memory.

\section{Method}

The hypotheses are examined with data of multiple elementary schools located in Jakarta (urban area) and Semarang (rural area), collected via consumer surveys. Because of the number of constructs in the model and the complex relationships among them, it is best to test the hypotheses in two or more parts before testing the entire model. Before conducting empirical tests, extensive qualitative research has been conducted (focus group discussion and in-depth interviews) with 12 children in Jakarta as a first step to validate the questionnaires and to propose the aforementioned model. This research will not only help generate a list of constructs with which children are likely to identify, but also develop new measures or refine existing key constructs. Subject-matter-experttech- 
Haryanto-The Role of Intention to Consume in Creating Autobiographical Memory

nique is also harnessed to check all the questions, constructs, and logics behind the questionnaires (with two experts specializing in children and one expert in children psychology). This is conducted to propose understandable languages and questions for the children. Prior to this empirical examination, however, pretests are conducted to validate the adaptation of existing scales. In conclusion, there are two pretests conducted before the empirical tests: (1) a pretest to check the proposed model and (2) a pretest to check the understanding of the questions.

\section{Pretests Study}

For the pretests, survey data are collected using a convenience sampling of 30 elementary students in Semarang and 30 elementary students in Jakarta. Measures are captured relative to the services of fast food restaurant McDonald's. The aim of these pretests is to examine the scales that would be used to test the model.

\section{Measurement}

Construct measurement uses scales from Cook (2000), adapted for the children examined. To make children easier in answering the questions, the measures will use 'emotion pictures' (Figure 2) with a four-point Likert scale (from strongly disagree to strongly agree) There are two sets of show cards that describe boys and girls. These show cards are adapted from (Cook 2000). The original version comprises a seven-point scale (strongly disagree, moderately disagree, disagree, neutral, agree, moderately agree, strongly disagree), but the pretests and

Figure 2. Show Card Emotion Picture

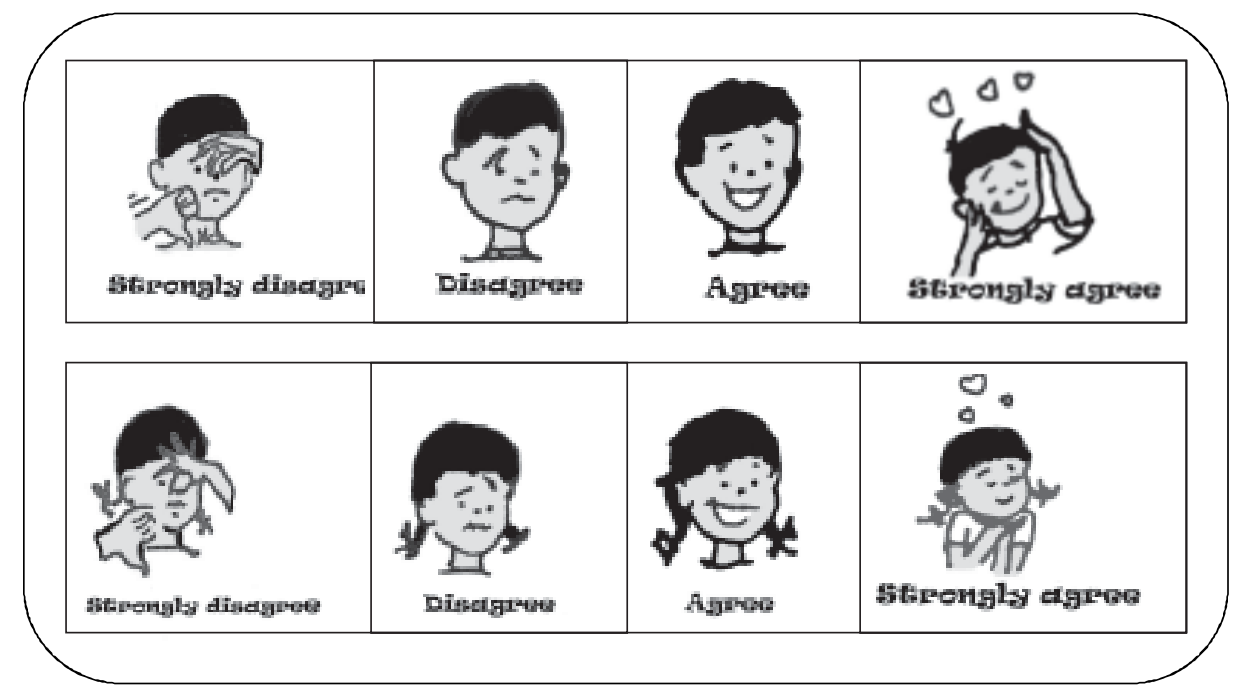

Source: Adapted from Cook (2000). 
Gadjah Mada International Journal of Business, September - December 2008, Vol. 10, No. 3

FGD find that the children could not differentiate between moderately agree and agree, or moderately disagree and disagree. Hence, the author decides to modify the scale into a four-point Likert scale.

Results from the pretests show that the reliability of all scales is adequate given Nunnally's (1978) standard. Some questions, which appear to be problematic based on respondents' comments in pretests, are reworded in the main study.

\section{Main Study}

Elementary schools in Semarang and Jakarta are randomly selected from a database. Data are taken from 10 state elementary schools in Semarang and 10 private elementary schools in Jakarta. A final sample of 468 completed surveys (204 from Semarang and 264 from Jakarta) is obtained.

Approximately 60 percent of respondents are males, and the average of their allowances is IDR3,000-5,000 daily. The majority of the respondents go to McDonald's with their parents, and they spend between one and two hours there. Most of the respondents go to McDonald's three to five times monthly.

\section{Results}

Exploratory and confirmatory analyses are conducted. First, exploratory principal component analysis (varimax rotation) and reliability analysis are performed to refine the scales. For all constructs, a one-dimensional structure is found.

A confirmatory factor analysis (CFA) using LISREL 8.73 with maximum-likelihood (ML) estimation (Joreskog and Sorbom 1993) is then performed on the scales. To assess the model, multiple fit indexes are reported. Four assessments, commonlyused fit indexes, are reported: goodness-of-fit Index, root mean square

Table 1. Structural Equation Model

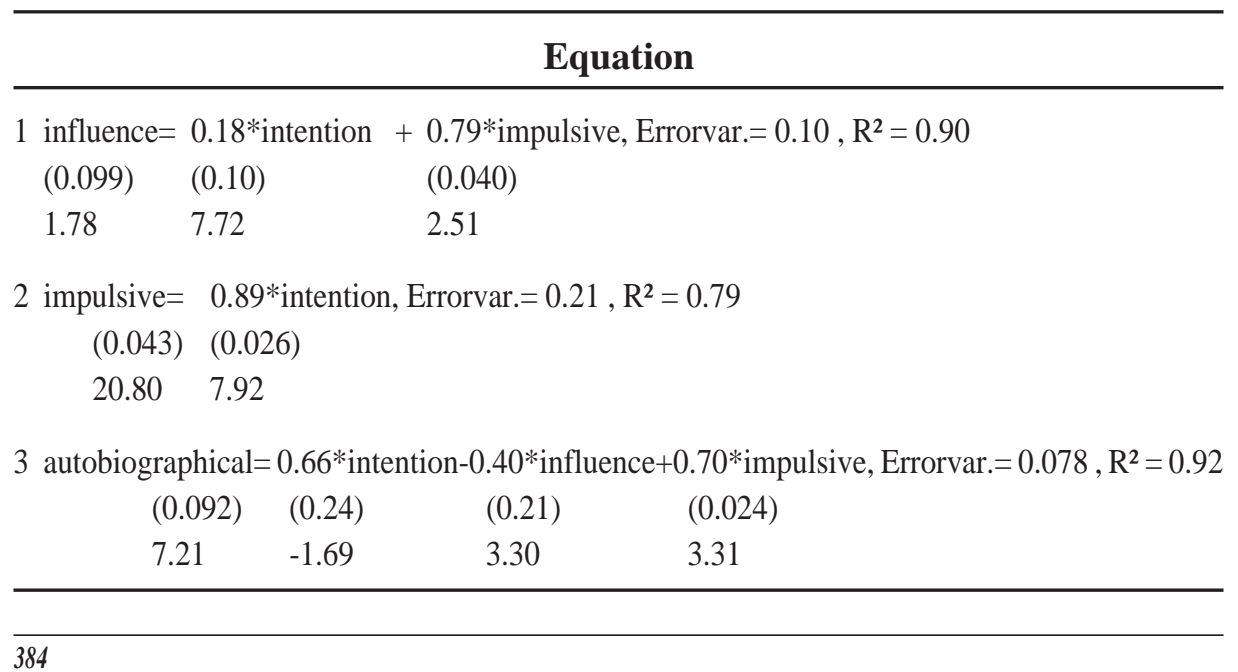


Haryanto-The Role of Intention to Consume in Creating Autobiographical Memory

error of approximation (RMSEA), normed fit index (NFI), and comparative fit index (CFI). Standardized data are used for all subsequent analyses. The process of standardization is to eliminate bias introduced by the difference in scales of several attributes or variables used in the analysis (Hair et al.1995). Overall model fit indexes indicate that the CFA model is consistent with the data, with all fit indexes equal to, or better than, recommended values $(\mathrm{GFI}=.94$, RMSEA $=.048$, $\mathrm{NFI}=.99$, CFI $=.99$ ).

\section{Table 2. Result of Structural Model Relationship}

\begin{tabular}{|c|c|c|c|}
\hline Hyphotesis & Hyphotesis Statement & t-value & Supported/Not \\
\hline H1 & $\begin{array}{l}\text { The stronger the intention to } \\
\text { consume for kids, the higher } \\
\text { their possibility to conduct } \\
\text { an impulsive buying }\end{array}$ & 1.78 & Supported \\
\hline$H 2$ & $\begin{array}{l}\text { The higher their intention to } \\
\text { consume, the stronger kids } \\
\text { influence parents to conduct } \\
\text { a purchasing }\end{array}$ & -1.69 & Not Supported \\
\hline H3 & $\begin{array}{l}\text { The higher kids' desire to } \\
\text { conduct an impulsive buying, } \\
\text { the stronger they will influence } \\
\text { parents. }\end{array}$ & 7.21 & Supported \\
\hline H4 & $\begin{array}{l}\text { The stronger the intention to } \\
\text { consume then the stronger } \\
\text { autobiographical memory which } \\
\text { is developed between the kids } \\
\text { and the product. }\end{array}$ & 8.56 & Supported \\
\hline H5 & $\begin{array}{l}\text { The stronger the pester power, } \\
\text { the stronger the autobio- } \\
\text { graphical memory which } \\
\text { is developed between the kids } \\
\text { and product. }\end{array}$ & 1.37 & Not Supported \\
\hline H6 & $\begin{array}{l}\text { The more often an impulsive } \\
\text { buying to specific products, the } \\
\text { stronger autobiographical } \\
\text { memory. }\end{array}$ & 0.79 & Not Supported \\
\hline
\end{tabular}


Gadjah Mada International Journal of Business, September - December 2008, Vol. 10, No. 3

\section{Discussion}

From the analysis above, the author finds some antecedents of autobiographical memory for kids in Semarang and Jakarta. From the equation, it is found that the intention to consume significantly influences impulsive buying ( $\mathrm{H} 1$ is substantiated by the data). When kids have intentions to consume, they will be stimulated to conduct impulsive buying. They demand for the products right away and do not expect procrastination. For younger kids (four to six years old), they will cry or get angry should they not get what they want (temper tantrum). For kids in this research, this phenomenon does not appear, but still they want to get what they want immediately. Intention to consume can be considered a driver for kids to conduct impulsive buying. If marketers are able to stimulate the intention to consume, they will reap benefits from kids purchasing through impulsive buying. From in-depth interviews with the kids, it can be learned that they are very emotional, meaning that if they have an intention to consume, they will exercise the impulsive buying.

On the other hand, the intention to consume does not affect the influence power significantly (H2 is not supported by the data). The wants of kids are not necessarily able to push kids to influence their parents. This could happen due to several factors. Firstly, according to Acuff and Reiher (1997), children aged 10-12 years begin to abandon their childhood characters.
They no longer desire fantasy or imaginative toys. Although they are still on the emotional stage, in these ages they begin to be more mature and think rationally. Consequently, when children have the intention to continue consuming a product, they will not utilize their influence power to obtain the product. On the other hand, children start to figure out other strategies to obtain the product rather than using their influence power. Secondly, children in these ages, according to Sadock and Sadock(2007), feel ashamed when they desire something and have to ask from their parents. Children begin to think that the influence power is used only when they are young, and thus they abandon the influence power when they desire something. However, the influence power does exist when children desire more luxurious products, such as computer, bicycle, or other expensive goods. This tendency encourages children not to utilize the influence power when they have the intention to consume McD. Thirdly, based on the FGD, it is identified that kids actually use their influence power, but it is primarily used for highly involved products, such as expensive toys or games.

Impulsive buying significantly influences the influence power (H3 is substantiated by the data). Kids who have the intention to conduct impulsive buying will use their influence power to obtain it. This impulsive buying is used as a reflection of kids' selfconcept. The finding implies that kids use impulsive buying to show their 
existence into the world. This explains the fact that whenever they want to conduct impulsive buying, they will use their influence power to get what they want. Children are usually positioned as an influence market, i.e., they influence parents to purchase for them. In this market, children do not spend their own money. This could explain as to why they utilize the influence power whenever they want to conduct impulsive buying.

Intention to consume significantly influences the autobiographical memory (H4 is supported by the data). The intention to consume for kids has become a specific desire, and this want will be memorized as an autobiographical memory. It becomes stronger when kids find difficulties obtaining their desires. For fulfilled wants, kids will memorize them as pleasant memories. From in-depth interviews, it is found that the intention to consume functions as emotional bonding, which brings the development of an autobiographical memory.

Influence power has no significant influence on the autobiographical memory (H5 is not supported). Kids basically use their influence power to obtain their wants all the time. This makes the influence power more ordinary and not be memorized in autobiographical memories of the kids. This could happen subsequent to the combination of sample of children in Jakarta and Semarang. When data from Semarang are run independently, it is observed that the influence power does influence the autobiographical memory. Hence, it is conjectured that the children in Jakarta (urban area) consume McD as a convenience product, and this has made the influence power less powerful. For further explanation, children also learn that the same strategy could not be used several times. Therefore, they have to change strategies in order to get what they want. These various strategies lead kids to experience difficulties memorizing them.

Impulsive buying affects the autobiographical memory significantly (H6 is confirmed). Kids conduct impulsive buying to establish their selfconcept. This impulsive buying is utilized to show their existence into the world. Getting what they want immediately, children will be very delighted and they will memorize it as an autobiographical memory. Based on the FGD, it is learned that the fulfillment of needs and wants through impulsive buying shows the kids that they are loved by their parents, and they memorize this as an autobiographical memory.

\section{Theoretical Implications}

Autobiographical memory is an interesting subject to be explored in marketing domain. However, research on the development of autobiographical memory is still limited. This study's findings challenge some aspects of our current understanding of autobiographical memory. Influence power and impulsive buying have not been deemed to be important factors in creating autobiographical memories of 
kids aged 10-12 years. This research shows that the intention to consume is much more important for kids' autobiographical memories compared to the influence power as well as the impulsive buying.

In this study, the intention to consume is not an important factor for 1012 year-old kids to influence their parents to buy $\mathrm{McD}$. The existing paradigm that positions the influence power as a critical factor in the development of autobiographical memory needs to be reexamined. In the $\mathrm{McD}$ consumption case, it is found that kids do not memorize events when they influence parents for a particular product they want. This finding indicates that kids between 10 and 12 years old do not use the influence power anymore when they want low-involvement products. They prefer to purchase the products on their own rather than asking parents for them.

\section{Managerial Implications}

An understanding of the relative impacts and interactions among intention to consume, impulsive buying, and influence power spares marketers an opportunity to design more effective customer acquisition and/or retention programs. Marketers need to put an emphasis on stimulating the intention to consume in order to create a positive autobiographical memory. For instance, the development of product characteristics and retail environment could be used to stimulate the intention to consume.
Due to the high conformity for kids, marketers have to start thinking about stimulating the group as a whole in order to attract attention from the kids. The main role of marketers is to stimulate kids' intentions to consume. If kids already have the intention to consume, they will be led to conduct impulsive buying, and this will be memorized as an autobiographical memory. This finding implies that the intention to consume is only one among other factors examined in this research that can create an autobiographical memory. Therefore, marketers need to prioritize it through specific marketing programs.

\section{Limitations}

There are some important caveats associated with this study. It is recognized that the survey setting has some constraints. While the benefit of this model is the inclusion of interactive effects, the use of a survey limits the ability to detect interactions (McCleland and Judd 1993). In this study, only the most commonly studied drivers of the autobiographical memory are incorporated into the model. Efforts should be made in future research to incorporate additional dimensions underlying the intention to consume and the autobiographical memory. As a result, the generalizability of the findings could be improved by empirical examination in other settings of autobiographical memory. 
Haryanto-The Role of Intention to Consume in Creating Autobiographical Memory

\section{Conclusion}

This model provides a useful tool for assisting managers in mapping the competing forces that influence the autobiographical memory of customer. The variables examined in this study provide a starting point. More importantly, this study suggests that the autobiographical memory is less influ- enced by impulsive buying and influence power than by intention to consume. As discussed here, the marketing-for-kids literature has much to offer to those who are interested in understanding kids as customers. However, research on memory development and consuming intention is still limited. Hopefully, this study may arouse further interest in this area.

\section{References}

Abratt, R., and S. D. Goodey. 1990. Unplanned buying and in-store stimuli in supermarkets. Managerial and Decision Economics 11: 111-121.

Acuff, D. S., and H. R. Robert. 1997. The Psychology of Marketing to Kids: What Kids Buy and Why. New York: The Free Press.

Berkman, H. W., J. D. Lindquist, and M. J. Sirgy. 1997. Consumer Behavior. Chicago, IL: NTC Publishing Group.

Berntsen, D., and D. C. Rubin. 2002. Emotionally charged autobiographical memories across the lifespan: The recall of happy, sad, traumatic, and involuntary memories. Psychology and Aging 17: 636-652.

Braun, K. A., R. Ellis, and E. F. Loftus. 2002. Make my memory: How advertising can change our memories of the past. Psychology and Marketing 19 (Iss. 1): 41-70.

Brown, K. D. 1998. Design in the british toy industry since 1945. Journal of Design History 11 ( 4): 323-333.

Cobb, C. J. and W. D. Hoyer. 1986. Planned versus impulse purchase behavior. Journal Retail 62: 67-81.

Cook, D. T. 2000. The other child study: Figuring children as consumers in market research 1910-1990s. The Sociological Quarterly 41 (3): 487-507.

Darley, W. F., and J. S. Lim. 1986. Family decision making in leisure time activities: An exploratory investigation of the impact of locus of control, child age influence factor and parental type on perceived child influence. In Richard J. Lutz (Ed.). Advances in Consumer Research 13. Provo, UT: Association for Consumer Research: 370-375.

Dittmar, H., and J. Drury. 1998. Self-image - Is it in the Bag? A qualitative comparison between "ordinary and excessive consumers. Journal of Economic Psychology 21: 109-142.

Erikson, E. H. 1950. Childhood and Society. New York: Norton.

Press. . 1959. Identity and the Life Cycle. New York: International Universities 
Gadjah Mada International Journal of Business, September - December 2008, Vol. 10, No. 3

Foxman, E., P. S. Tansuhaj, and K. M. Ekstrom. 1989. Family members' perception of adolescents influence in family decision-making. Journal of Consumer Research (March): 482-491.

Gunter, B., and A. Furnham. 1998. Children as Consumers: A Psychological Analysis of the Young People's Market. London: Routledge.

Hair, J. F., R. E. Anderson, R. L. Tatham, and C. B. William. 1995. Multivariate Data Analysis. NJ: Prentice Hall: Englewood Cliffs.

Hausman, A. 2000. A multi-method investigation of consumer motivations in impulse buying behavior. Journal of Consumer Marketing 17 (5): 403-419.

Holdert, F. and G. Antonides. 1997. Family type effects on household members' decision making. Advances in Consumer Research 24: 48-54.

Isler, L., E. T. Popper, and S. Ward. 1987. Children's purchase requests and parental responses: Results from a diary study. Journal of Advertising Research, 27 ( October), 28-39.

John, D. R. 1999. Consumer socialization of children: A retrospective look at twenty-five years of research. Journal of Consumer Research 26: 183-213.

Joreskog, K. G., and Dag Sorbom. 1993. Latent variable scores and their uses. Retrieved from http://www.ssicentral.com/lisrel/column6.htm

Lindstorm, M., and P. B. Seybold. 2007. Top Brand Anak and Remaja. Jakarta: Penerbit PPM.

McNeal, J. U. 1992. Kids as customers. Handbook of Marketing to Children. New York: The Free Press. Publishing.

McNeal, J. U., and C. Hwa Yeh. 1996. Consumer behavior patterns among Chinese children. Asia Pacific Journal of Marketing and Logistics 8: 3-19.

Nicholls, A., and P. Cullen. 2003. The child-parent purchase relationship: 'Pester Power', human rights and retail ethics. Journal of Retailing and Consumer Services 11: 7586.

Nunnally, J. C. 1978. Psychometric Theory ( $2^{\text {nd }}$ Ed.). New York: McGraw-Hill.

Peck, J. and T. L. Childers. 2006. If I touch it I have to have it: Individual and environmental influences on impulse purchasing. Journal of Business Research 59: 765-769.

Ramanathan, A., and G. Menon. 2002. Don't know why, but I had this craving: Goaldependent automaticity in impulsive decisions. Working Paper. New York University.

Rook, D. W. 1987. The buying impulse. Journal of Consumer Research 14: 189-199.

Rook, D. W., and R. J. Fisher. 1995. Normative influences on impulse buying behavior. Journal of Consumer Research 22: 305-313.

Rubin, D. 2006. Autobiography memory. Journal of Child and Psychiatry 37: 286-329.

Sadock, B.J. and V. A. Sadock. 2007. Synopsis of Psychiatry. New York: Lippincott Williams and Wilkins. 
Haryanto-The Role of Intention to Consume in Creating Autobiographical Memory

Santrock, J. W. 2001. Child Development ( $9^{\text {th }}$ ed.). New York: Irwin McGraw Hill.

Shoham, A., and V. Dalakas. 2003. Family consumer decision making in Israel: The role of teens and parents. The Journal of Consumer Marketing 20 (3): 238-251.

Solomon, M. R. 2007. Consumer Behavior. New Jersey: Prentice Hall.

Sutjan, M., J. R. Bettman, and H. Baumgartner. 1993. Influencing consumer judgments using autobiographical memories: A self-referencing perspective. Journal of Marketing Research 30: 422-36.

Ward, S., and D. Wackman. 1972. Children's purchase influence attempts and parental yielding. Journal of Marketing Research 9 (November): 316-319.

Williams, L. A., and A. Veeck. 1998. An exploratory study of children's purchase influence in urban China. Asia Pacific Advances in Consumer Research 3: 13-19.

Yusuf, E. Z. 2007. Sikap anak Indonesia terhadap merek. Seri Manajemen Pemasaran 19. Jakarta: Penerbit PPM.

Zoll, M. H. 2000. Corporatization of education: Psychologists challenge ethics of marketing to children. American News Service 5 (April): 72-90. 